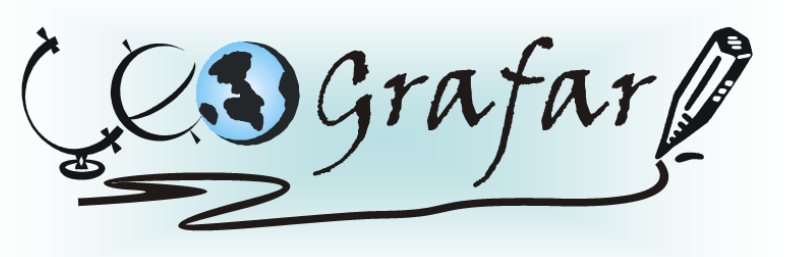

Revista Eletrônica do Programa de Pós-Graduação em Geografia - UFPR

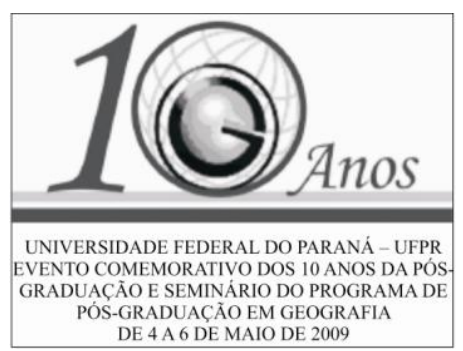

\title{
O PAPEL DAS FORMAS FÍSICAS E SIMBÓLICAS NA CONSTRUÇÃO DO INDIVÍDUO PÓS-MODERNO
}

\author{
SILMARA DIAS FEIBER ${ }^{1}$ \\ SALETE KOZEL ${ }^{2}$ \\ LINHA DE PESQUISA: TERRITÓRIO, CULTURA E REPRESENTAÇÃO.
}

\section{INTRODUÇÃO}

A organização do espaço por meio de elementos visíveis da paisagem é assunto pertinente tanto do saber geográfico como da história e teoria da arquitetura. O estímulo em se desvendar e compreender as práticas sociais que se desenvolvem dentro das relações entre o homem e seu ambiente oferta uma rica experiência em que a geografia e a arquitetura podem caminhar juntas na compreensão das formas espaciais - físicas e simbólicas - que formam a base do indivíduo pós-moderno.

A construção social do indivíduo surge num emaranhado de relações que unem o real e o imaginário e refletem significativamente nas suas ações cotidianas. Em acordo com esta idéia e para colaborar na compreensão destes fenômenos, Berger e Luckmann (2003, p.35) relatam que o principal objeto da análise sociológica é esta realidade da vida cotidiana, segundo os autores esta "apresenta-se como uma realidade interpretada pelos homens e subjetivamente dotada de sentido para eles na medida em que forma um mundo coerente...”. Assim as formas geográficas de organização espacial unida à presença do espaço arquitetural, em sua materialidade, fornecem a base onde este indivíduo constrói suas relações e por vezes se submete a elas numa posição de subserviência e falta de controle de sua própria individualidade. Pois, assim como os autores acima citados, acredita-se que a realidade é envolta em fenômenos que por vezes são reconhecidos, porém independem de nossa própria vontade e é este conhecimento, esta apreensão da realidade, que nos conduz na vida diária.

\footnotetext{
1 silmaradias@fag.edu.br; sdfeiber@pop.com.br

${ }^{2}$ Professora orientadora
} 
A linguagem expressa nas obras arquitetônicas instiga esta pesquisa sobre a possível influência dos espaços urbanos e arquitetônicos na medida em que estes passam a ser o espaço cotidiano dos indivíduos ao longo de sua existência. Pois, segundo Moscovici (2003, p.155) a cultura (acrescenta-se aqui a cultura arquitetônica) se cria por meio da comunicação e esta é regida por princípios organizacionais que refletem as relações sociais que são implícitas neste fenômeno de comunicação. Ainda no pensamento do autor a organização que rege as relações sociais possui uma história, leis e dinâmica própria da sociedade que a criou e por isto não pode ser derivada de leis exteriores a este sistema.

Neste contexto, o tema de pesquisa proposto visa resgatar o pensamento sobre as questões simbólicas presentes no espaço cotidiano, materializado nas formas e espaços arquitetônicos, e sua relação com os grupos sociais que atuam neste espaço. Esta visão do imaginário contido na interpretação de objetos físicos envoltos por valores culturais diversos pode ser o indicador da falta de fixação dos indivíduos pós-modernos numa estrutura social estabilizada. A história contada por meio das configurações espaciais materializa o pensamento de uma sociedade, esta passa a ser o produto do meio que a gerou ao mesmo tempo em que é influenciada por ele. Neste contexto Argan (2005, p.243) coloca, a respeito das cidades modernas, que estas estão sendo formadas por "montanhas de refugos arquitetônicos que a especulação descontrolada acumulou nas cidades" e que este é o resultado de uma cruel realidade política e social contemporânea.

\section{INSERÇÃO TEMÁTICA DO ESTUDO EMPÍRICO}

O mundo atual possui no âmbito de suas dimensões físicas e espaciais uma extrema mobilidade o gera uma grande complexidade de valores e de sentidos. Este processo dinâmico traz consigo muitas vezes uma crise de identidade dos indivíduos principalmente em relação à parcela do espaço que ocupam. Quando analisamos a identidade num contexto sociológico esta aparece, segundo Giddens (2005, p.44), como um produto de determinados contextos históricos e sociais que formam um indivíduo ou um grupo social através de experiências históricas e significativas. Assim, o conceito de identidade alia-se ao enfoque antropológico que a define como um processo semiótico, o qual estabelece para o indivíduo uma dimensão de pertencimento a uma comunidade, seja uma nação, uma etnia, um gênero ou uma classe social. Nas pesquisas de De Botton (2007, p.32) a essência da arquitetura (vista aqui como um produto social e cultural) demonstra por meio de sua materialidade certos estados de espírito 
que desejam "incentivar e sustentar". Segundo o autor enquanto a presença das obras e espaços arquitetônicos nos envolve fisicamente "nos convidam a sermos tipos específicos de pessoas".

Dentro deste discurso a atual falta de estabilidade do indivíduo pós-moderno serve de estímulo para a hipótese de pesquisa que foi em busca de um exemplo de "sociedade ideal", criada a partir de um espaço sem organização espacial pré-existente, para poder investigar o real papel das formas simbólicas no desenvolvimento e transmissão de uma cultura. Esta investigação delimitada pelo espaço-tempo das reduções jesuíticas na Região do Prata, onde o ideal da Companhia de Jesus foi materializado no espaço físico das reduções, acredita-se ser uma fonte rica que poderá subsidiar a verificação da tese pretendida colaborando para a compreensão dos fenômenos espaciais que atuam na atual formação da sociedade contemporânea e que estão, por hora, adormecidos. Neste sentido Moscovici (2003, p.57) alerta que o pensamento social, o qual é refletido nas representações sociais, está enraizado com maior profundidade nas convenções e memória coletiva do que a razão. Portanto é pertinente que traga à tona a existência de tais processos para que possamos contribuir com uma nova visão a respeito da influência das formas espaciais na formação e desenvolvimento humano das sociedades contemporâneas.

\section{CONSIDERAÇÕES}

Esta suposição levantada pelo tema de pesquisa visa enfocar o poder que as formas simbólicas provenientes da arquitetura possuem, ainda no âmbito de hipóteses, em sua materialidade. Pois, conforme o autor supracitado as principais formas do ambiente físico e social se fixam por meio das representações. Estas possibilitaram, em tese, que o poder de persuasão e de convencimento dos jesuítas se propagasse no processo de aculturação. A Geografia Humanística Cultural forma o canal por onde se acredita encontrar a base da compreensão dos assuntos aqui tratados. Além desta, as contribuições da sociologia, filosofia e psicologia social vêm a enriquecer o entendimento sobre os processos desenvolvidos num espaço específico por incorporar as experiências vividas em suas análises, formam assim a base onde se busca compreender, por meio do estudo do espaço e suas relações sociais, a problemática sugerida pos esta pesquisa.

A contribuição pretendida com esta pesquisa é de trazer à tona a reflexão sobre os processos culturais que permeiam as formas arquitetônicas e de organização espacial que, 
acredita-se, acabam por refletir nos modos de ser e de viver de uma sociedade que se pretende estável. Para isto pretende, num primeiro momento, aprofundar as pesquisas bibliográficas buscando subsídios na teoria da arquitetura, teoria da estética, geografia cultural, sociologia, filosofia e psicologia social para formar uma base sólida de conhecimento que vá contribuir para o esclarecimento da tese sugerida. Especificamente a estética será analisada nos moldes da interpretação fisiopsicológica de Zevi (2002, p.161) o qual questiona a simples análise estilística e busca diante da teoria de Einfuhlung a análise dentro da identificação do espectador com as formas. Pois, segundo o autor a presença das formas arquiteturais nos faz "vibrar em simpatia simbólica" com elas posto que as obras causam reações tanto em nosso corpo como em nosso espírito.

\section{REFERÊNCIAS}

ARGAN, Giulio Carlo. História da arte como história da cidade. São Paulo: Martins Fontes, 2005.

BERGER, Peter L., LUCKMANN, Thomas. A Construção Social da Realidade. Petrópolis: Ed. Vozes, 2003.

DE BOTTON, Alain. Arquitetura da Felicidade. Rio de Janeiro: Rocco,2007.

GIDDENS, Anthony. As conseqüiências da modernidade. São Paulo: Editora UNESP,1991.

MOSCOVICI, Serge. Representações sociais: investigações em psicologia social. Petrópolis: Vozes, 2003.

ZEVI, Bruno. Saber Ver a Arquitetura. São Paulo: Martins Fontes, 2002.

Palavras-chave: Geografia Cultural, Arquitetura, Identidade. 